\title{
The Performance of Public Libraries in Negros Occidental, Philippines
}

\author{
Ruvy M. Tuble \\ Carlos Hilado Memorial State College-Fortune Towne, Philippines \\ ruvy.tuble@chmsc.edu.ph \\ https://orcid.org/0000-0002-8204-0107 \\ Ma. Johanna Ann R. Bayoneta \\ University of Negros Occidental-Recoletos, Bacolod City, Philippines \\ johannaannbayoneta@gmail.com
}

\begin{abstract}
This descriptive research examined the state of public libraries in Negros Occidental as to its compliance with RA 7743; its performance based on standard requirement; and implementation of greening practices to 31 administrators and 379 users. Findings revealed that most of the provisions of the law were not complied as indicated by the number of municipalities without libraries, the appointment of a non-professional librarian, and the inadequacy of budget allocation. Likewise, assessors find their performance as good but distinctively rated IT facilities and services as poor. In the implementation of sustainable practices, administrators rated it great, while users find it to a moderate extent. The challenges encountered by assessors conveys a clear message that public libraries are striving to fulfill its philosophy of existence. Thus, broader knowledge and understanding of local authorities and the community of the vital role public library plays in nation-building shape its future.
\end{abstract}

Keywords: Public Administration and Governance, Public Libraries, Descriptive, Negros Occidental, Philippines

Date Submitted: September 29, 2019

Date Revised: December 14, 2019

Date Accepted: December 29, 2019

\subsection{Introduction}

Public libraries are widely considered as a powerful partner towards sustainable development because of its accessibility to knowledge, information, and works of the imagination through an array of resources and services to all constituents of the society regardless of race, origin, age, gender, religion, language, disability, economic and employment state, and educational accomplishment (IFLA/UNESCO Public Library Manifesto, 2010 cited in Otolo, 2016). Leaders across the globe considered public 
libraries as an essential component of their country's literate population (Michnik, 2015). Likewise, to support the global advocacy of protecting nature for the present and future generations greening practices are being merged in the modern library management process (Datta, 2015).

In the Philippines, as stated in the 1987 Constitution, it is a national policy to promote the intellectual well-being of every citizen in harmony with well-protected ecology (De Leon \& De Leon, Jr., 2017). In elevating the literacy level of every Filipinos, Local Government Units through RA 7743 are mandated to establish and maintain public libraries. Despite enabling laws in promoting universal access to information, there are still cities and municipalities in the country with the unserviceable public library or not existing at all. In the province of Negros Occidental, the 2015 National Library of the Philippines report discloses that only 20 from the 31 component cities and municipalities have active libraries status (Santos, 2015). Data further shows that 11 local government units had disregarded the implementation of the twenty-four-yearold legislation. Further, the existing public libraries are lagging in terms of development. Deloso (2010) revealed that the majority of the public libraries in the province did not conform to minimum requirements, particularly in the areas of personnel, collections, facilities, and services because of the least budgetary allocation it receives from the Local Government Officials.

Several studies have been made in the past to evaluate public libraries in the country and abroad (Deloso, 2010; Alaya-ay, 2013; Laspinas, 2015; Myers \& Heddon, 2017), hence, focused either on criteria of public library law or on the standards developed for public libraries which in the best way utilizes 4-5 parameters. No local studies had been conducted regarding how sustainable practices are being implemented in public libraries.

On this premise, the researcher wanted to assess the current state of public libraries in the province by employing 12 parameters in view of evaluating three distinct phenomena not only to address the scarcity of data on this field but to merit contribution in providing a reliable, clearer picture, and inclusive evidence to help in the development and strengthening of the image of this institution. The uncovered inefficiencies, therefore, will be given recommendations tantamount to meeting the information needs of the community.

This study aimed to assess the state of the public libraries in the province of Negros Occidental. Specifically, it sought to determine the status of compliance of public libraries in the province as to the provisions of RA 7743 in the areas of administration, human resources, and financial resources; assess the level of performance of the public libraries in the areas of collection management, services and utilization, physical facilities, and information technology facilities and services when assessed by administrators and users; assess the extent of implementation of sustainable practices in greening public libraries in the areas of location, power and utilities, materials and resources, indoor environment, and operations and design when assessed by administrators and users; and, to identify the challenges of public libraries in maintaining its relevance and value in the community. 


\subsection{Framework of the Study}

This study is anchored on compliance, performance management, and green library management theories. Compliance theory, as posited by Etzioni (1964), hypothesizes that organizations are performance directed, goal-oriented, and ensure compliance through their power structure. In situations when compliance does not occur, it is due to weaknesses in the planning, enforcement of policies or regulations, and commitment of their members. Based on this supposition, LGUs being highly committed to their constituents acknowledges the tangible and intangible influence of the public libraries to nation-building and as a result, will fulfill their responsibilities by following the provisions stated in RA 7743. The local chief executives with the librarians and officers in charge are persuasive in actions specifically in establishing and maintaining a functional, relevant, and effective public library because it was the right thing to do (Baxter, 2015; Traska, 2015).

The performance theory of Thomas W. Buchner states that an organization performs systematically by setting strategic goals, measure; collect and analyze data; review performance data reported; and applying the results to improve the overall performance of an organization (Tabatabai, Karbasian, \& Mirbagheri, 2014). A strong performance requires a positive inherent value of efficacy in addition to appropriate skills and abilities (Iroaganachi \& Nkiko, 2016). By using this theory, organizations can develop their performance measures and then reports the finding for further improvement, and in this, a continuous process keeps running. In this study, appraising the performance of public libraries on the facet of administrators and users using the Standard for Philippine Public Libraries criteria will ensure the achievement of the organization's vision strategically. The metric is designed to tell what really has to perform and how effectively it must have to perform to remain relevant and pertinent, particularly in today's environment. The performance feedback promotes regular checking of the strengths and weaknesses and allows the library administrators to design approaches for the improvement of services, resources, and facilities offered to community users (Orlopia \& Rabacca, 2014).

The theory of green library management, which was introduced by the University of Mauritius Library in 2003, had been put into practice by different types of libraries all over the world. It specifically calls for conscious awareness of the environment and devising strategies at administering library resources and services with environmental consideration at the forefront. Green library management highlights a new mindset of assuming responsibility for the health of library users and staff and providing for the needs and interests of future generations of users, and nature's stability (Ephraim, 2003 cited in Bell \& Cottrell, 2015). In line with this, public libraries, as frontline advocates of information, embrace policies and decisions aligned with sustainable development agenda. The study wanted to gauge how public libraries are implementing greening practices that will safeguard the internal and external environment by reducing pollution, minimizing the use of energy and resource consumption, as well as in ensuring that the use of the library is less hazardous to health.

In this framework, it is speculated that public library is in upright state if its management, staffing, and funding components conform with the provisions stated in the enacted legislation; if its resources, services, and facilities meet standard 
requirement design for such purpose, and if greening practices are instigated in the constructs of location, power and utilities, materials and resources, indoor environment, and operations and design. LGUs being highly committed to their constituents should fulfill their responsibilities by following the provisions of RA 7743 in establishing and maintaining a functional, relevant, and effective public library because it was the right thing to do. The performance feedback, on the other hand, promotes regular checking of the strengths and weaknesses and allows the library administrators to design approaches for the improvement of services, resources, and facilities offered to community users.

\subsection{Methods}

The study employed the descriptive and comparative approach to measure the status of compliance with RA 7743, level of performance, and extent of implementation of sustainable practices of public libraries.

The respondents of this study were the 31 administrators comprising of seven local chief executives, six official-designates, two professional librarians, and 16 officers in charge; and, 379 library users consisting of 141 students, 36 out-of-school youths, 102 employed citizens, 45 unemployed citizens, 48 senior citizens, and seven persons with disability.

The status of compliance to RA 7743 was assessed by the administrators of LGUs, both with or without public libraries. Furthermore, administrators and users of the LGUs with active public libraries in the province answered the questionnaire for the level of performance and extent of implementation of greening practices. Respondents of the interviews were the provincial director of the Department of Interior and Local Government, selected local chief executives, other key officials, librarians, officers in charge, and selected library users in the community.

The data were gathered using a researcher-made survey questionnaire and an interview list. The survey instrument was patterned from the statutory requirement stipulated in the provisions of RA 7743, from the standard designed for public libraries in the country, and from the literature using green assessment checklists. The instrument was composed of five sub-sections, where Part I was designed to identify the participants' category. Part II assessed the status of compliance using a questionnairechecklist answerable by Yes or No. Part III measured the level of performance based on the parameters in the standard requirement for Philippine public libraries while Part IV measured the extent of implementation of the sustainable practices in greening public library. Both part III and IV questions are answerable by using a five-point scale Likerttype where the highest rating is 5, and the lowest is 1 . Criteria were set for corresponding rating scales. Part $\mathrm{V}$ covers the checklists of the challenges/problems encountered by administrators and users. The instrument was subjected to validity and reliability tests. The researcher surveyed the administrators from June to July 2018, and library users who utilize public libraries for July 2018. Purposive and convenience sampling methods were considered.

In gathering the data, the approval of the Dean of the Recoletos de Bacolod Graduate School and the local chief executives was secured before the conduct of the 
study. The respondents were oriented about the purpose and scope of the study, the nature, and parts of the questionnaire, and most especially the affirmation of their willingness to participate. They were assured of the full confidentiality of their answers. The materials that contained the raw information derived from them were disposed of by manual shredding, and digital data were deleted without any chance of retrieval.

Descriptive analyses were employed to analyze the data using appropriate statistical tools. The percentage was used in presenting the distribution of respondents in terms of their perceived status of compliance with RA 7743 and on the challenges they had encountered. Weighted mean and Standard Deviation were used for the level of performance and extent of implementation of sustainable practices of public libraries. Mean range with descriptive equivalence and interpretation was set to aid analyses and interpretation.

\subsection{Results and Discussion}

\section{Status of Compliance with RA 7743}

In the area of administration, only 58.1 percent $(\mathrm{N}=31)$ of the Local Government Units in the province of Negros Occidental is compliant with RA 7743 for establishing a public library in their locality. Those with public libraries are adherent to the law since all of the established public libraries were operating under the administrative supervision of the local chief executive or the duly designated local official. Also, the Inter-Agency Committee, specifically the National Library of the Philippines (NLP), was helping the local government from establishment to continuous development of the public library. However, it was noted that the local library board was not organized in every public library. Also, only 74.2 percent affirmed its inclusion in their local government comprehensive development plan.

It surfaced in the interview that the majority of the administrators and officers in charge were unaware of the specific content and the implementing rules and regulations of RA 7743. Thus, it neglected the establishment, re-activation, or improvement of public libraries or the creation of a local library board. Some officers in charge revealed that inclusion of library in the city/municipality development plan was not a guarantee that it will be realized because, based on their experience, the plan was often disregarded in favor of other social services.

The result of the study is in accordance with Alaya-ay (2013), Laspinas (2014), and Austria and Lozarie (2014) that not all LGUs had established a public library in their localities because of the local official's inadequate knowledge of the provisions of Republic Act 7743, lack of funds, and least priority level. Coherently, public library services are dependent on government bodies for decision making and funding (Salman, Mostert, \& Mugwisi, 2018). Thus, Rudzioniene and Dvorak (2014), Baxter (2015), and Traska (2015) are right that the public library is the responsibility of the upper-tier, particularly in setting strategic direction and financial concern in order to flourish.

Further, these findings imply that the twenty-four-year-old legislation (RA 7743) is arbitrarily complied and most likely neglected by some local officials because of the absence of sanction and principle of local autonomy. The noncompliance on the 
specific provisions of public library law is tantamount to the negligence of providing less fortunate residents of those municipalities with no public libraries with information services necessary for their educational development. Abandonment of library services in the picture of priorities is a manifestation of disregarding the global demands of providing all members of the community equitable and free access to information.

Table 1A. Status of Compliance to the Provisions of RA 7743 in the Area of Administration

\begin{tabular}{|c|c|c|c|c|}
\hline \multirow{2}{*}{ Provisions of RA 7743 as to Administration } & \multicolumn{2}{|l|}{ Yes } & \multicolumn{2}{|l|}{ No } \\
\hline & $f$ & $\%$ & $f$ & $\%$ \\
\hline $\begin{array}{l}\text { 1. There is a public library established in the } \\
\text { municipality or city. }\end{array}$ & 18 & 58.1 & 13 & 41.9 \\
\hline $\begin{array}{l}\text { 2. The public library has the local executive } \\
\text { or the duly authorized official of the } \\
\text { government units as its immediate } \\
\text { supervisor. }\end{array}$ & 18 & 58.1 & 13 & 41.9 \\
\hline $\begin{array}{l}\text { 3. There is an existing city or municipal } \\
\text { library board. }\end{array}$ & 0 & 0.0 & 31 & 100.0 \\
\hline $\begin{array}{l}\text { 4. The public library is included in the local } \\
\text { development plan. }\end{array}$ & 23 & 74.2 & 8 & 25.8 \\
\hline $\begin{array}{l}\text { 5. There is an Inter-Agency Committee that } \\
\text { hastens the implementation of the Law } \\
\text { and as the oversight committee for the } \\
\text { continued development of a public library. }\end{array}$ & 18 & 58.1 & 13 & 41.9 \\
\hline
\end{tabular}

Note: Yes $=$ Compliant No $=$ Not Compliant

As to human resources, only 6.5 percent $(\mathrm{N}=31)$ of the local government in the province complied with RA 7743 that a licensed librarian, occupying a plantilla position for librarian should man the public libraries. Results also showed that almost all are not compliant as to the adequacy of support staff (67.7 percent) and on hiring them with permanent status (77.4 percent). Nevertheless, it was interesting to note that all 18 LGUs with active libraries were sending their head librarians or officers in charge of training and seminars for professional growth and development.

The interview result stated that the non-conformity with RA 7743 in this context is attributed to the scarcity of professional librarians in the locality, lack of plantilla items for the librarian, financial constraint, and appointing official's lack of interest and support to fill out the position. Also, it was found out that the local autonomy tenets wherein local authorities have the power to govern their internal affairs, including libraries and that includes the authority and preference to hire under qualified personnel to the vacant position, was also a factor for non-compliance. The result of this study is incongruent with the findings of Deloso (2010); Alaya-ay (2013); Chandrasekar (2013); Agudelo (2014); Laspinas (2014); Otolo (2016); and Abban (2018).

The shortage of professional librarians, particularly those with the required qualifications and competencies to manage libraries have significant implication in Philippine librarianship. Throughout Negros Occidental, only one private higher educational institution has been offering a degree in library and information science. Graduates are not enough to cater to the needs of academic, special, school, and public libraries in the province. The need to find qualified personnel for libraries is a core 
issue. Thus, the appointment of nonprofessional librarian to manage and oversee public libraries is an option rather than closing the library because nobody is supervising it. However, as a consequence, the designated personnel's lack of formal education, professional skills, and competencies along library and information science affect the growth and functionality of most public libraries in the province.

Table 1B. Status of Compliance to the Provisions of RA 7743 in the Area of Human Resources

\begin{tabular}{|c|c|c|c|c|}
\hline \multirow{2}{*}{ Provisions of RA 7743 as to Human Resources } & \multicolumn{2}{|l|}{ Yes } & \multicolumn{2}{|l|}{ No } \\
\hline & f & $\%$ & f & $\%$ \\
\hline $\begin{array}{l}\text { 1. The library is manned by a licensed } \\
\text { librarian. }\end{array}$ & 2 & 6.5 & 29 & 93.5 \\
\hline $\begin{array}{l}\text { 2. The head librarian is a permanent } \\
\text { employee with a librarian plantilla } \\
\text { position. }\end{array}$ & 2 & 6.5 & 29 & 93.5 \\
\hline 3. There is an adequate library support staff. & 10 & 32.3 & 21 & 67.7 \\
\hline $\begin{array}{l}\text { 4. The library support staff occupies a } \\
\text { permanent plantilla position. }\end{array}$ & 7 & 22.6 & 24 & 77.4 \\
\hline $\begin{array}{l}\text { 5. Support for formal education, training, and } \\
\text { seminars are available for the professional } \\
\text { development of head librarian and library } \\
\text { staff. }\end{array}$ & 18 & 58.1 & 13 & 41.9 \\
\hline
\end{tabular}

Results also indicated that 38.7 percent of the public libraries were provided an annual budget to carry out adequately its plans and programs hence compliant to the provision of the Act. However, only 32.3 percent of the administrators found the budget adequate in hiring the required number of personnel; 16.1percent stated that it is sufficient to purchase equipment, furniture, fixtures, and other library materials; and 25.8 percent stated that it is enough to purchase books, subscription to serials, and other reference materials

In support, Quick et al. (2013), Austria and Lozarie (2014), and Katz (2017) found out that most public libraries had undergone budget cuts, especially in rural areas due to the widespread tight budgetary constraints in the public sector. Michnik (2015) validated that the funding situation of public libraries is expected to worsen since the government has other priorities. Wani (2016) added that even before the global economic turn down, many local and national governments had disinvested in public libraries.

The findings implied that most of the LGUs are not compliant with this construct. With limited funds, some of them could neither establish a library nor develop modern and innovative services. This is evident by its non-existence in the thirteen municipalities and the underdeveloped conditions of some existing public libraries in the province.

Overall, the non-compliance with the majority of the provisions in RA 7743, particularly in the areas of administration, human resources, and financial resources, hinders public libraries from becoming a primary source of knowledge and learning for readers and researchers. The findings validated the compliance theory that when compliance does not occur, it is due to weaknesses in the planning, enforcement of 
Table 1C. Status of Compliance to the Provisions of RA 7743 in the Area of Financial Resources

\begin{tabular}{|c|c|c|c|c|}
\hline \multirow{2}{*}{ Provisions of RA 7743 as to Human Resources } & \multicolumn{2}{|l|}{ Yes } & \multicolumn{2}{|l|}{ No } \\
\hline & f & $\%$ & f & $\%$ \\
\hline $\begin{array}{l}\text { 1. There is a regular annual appropriation to } \\
\text { carry out its plans and programs. }\end{array}$ & 12 & 38.7 & 19 & 61.3 \\
\hline $\begin{array}{l}\text { 2. The budgetary allocation is sufficient to } \\
\text { hire the required number of personnel. }\end{array}$ & 10 & 32.3 & 21 & 67.7 \\
\hline $\begin{array}{l}\text { 3. The budgetary allocation is sufficient to } \\
\text { purchase library equipment, IT equipment, } \\
\text { furniture, fixtures, and other library } \\
\text { materials. }\end{array}$ & 5 & 16.1 & 26 & 83.9 \\
\hline $\begin{array}{l}\text { 4. A budget is provided for the procurement } \\
\text { of books, subscription to serials, and other } \\
\text { reference materials. }\end{array}$ & 8 & 25.8 & 23 & 74.2 \\
\hline $\begin{array}{l}\text { 5. The utilization of the annual library budget } \\
\text { is at least } 85 \% \text {. }\end{array}$ & 4 & 12.9 & 27 & 87.1 \\
\hline
\end{tabular}

policies or regulations, and commitment of workforce and administrators. Salman, Mostert, and Mugwisi (2018) stated that the establishment and sustainability of the public library are dependent on a political decision. Alaya-ay (2013) and Handa (2018) pinpointed that conventional public library has implementers that recognized its importance in the field of learning and education of the citizenry. Thus, Biranvand, Soheili, and Khasseh (2015) and Otolo (2016) were correct that as public libraries conform to the standard requirements and provisions of the legislation, better services are offered to the community.

\section{Performance of public libraries}

The level of performance of the active and functional public libraries in the province as assessed by administrators $(M=2.89, \mathrm{SD}=0.50)$ and users $(\mathrm{M}=3.29, \mathrm{SD}=0.57)$ is good. Specifically, both assessors gave the highest rating $(M=3.57, S D=0.54 ; M=3.79$, $S D=0.54)$ to services and utilization and the least rating $(M=2.04, S D=0.85 ;(M=2.47$, $\mathrm{SD}=0.87$ ) to IT facilities and services, respectively. The very good performance indicates that public libraries met the standard requirements design in most respects. The result denotes that they were responsive to the information needs of its diverse users. It is noted that there were city libraries that receive awards and recognition for being one of the finalists for the best public libraries nationwide.

The above findings corroborate with Iwhiwhu and Okorodudu (2013) that public libraries' existence is based on its ability to render services which are meant to deliver their leading products to users. Valet (2013) agrees that public library performance is high if they were able to meet the standard requirement for services and utilization. On the other hand, the poor level of performance of public libraries in the area of IT facilities and services is an indication that ample endeavor is needed for them to serve as excellent repositories of information for users relating to new trends and technological advancement. The survey result underlined the weakness of the majority of public libraries in the provision of at least five computers with internet access, strong WiFi connection, and website for information dissemination. The finding is in line 
with the studies of Carungui (2015); Laspinas (2014); Orlopia and Rabacca (2015); and Watson (2013) that an ICT-enabled services in public libraries makes them relevant in this information era and this can only happen if library administrators will recognize the importance of libraries as a government partner in educating its citizenry. Pieprz and Sheth (2017) added that the concept of "lifestyle" libraries is practiced wherein there are café, music listening posts, and a virtual community for all types of users.

As a frontier analysis, the result entails that there is still a huge room for improvement that administrators may look into for the public libraries to remain functional and relevant in today's information era. The performance theory of Buchner substantiated the findings that assessing the performance of public libraries is a helpful tool to ensure quality provided it is done regularly. On this facet, conducting such study, issues, concerns, and plans of action to improve the condition of public libraries in the country, particularly in Negros Occidental, was materialized.

Table 2. Level of Performance of Public Libraries

\begin{tabular}{|c|c|c|c|c|c|c|}
\hline \multirow{2}{*}{ Areas } & \multicolumn{3}{|c|}{ Administrators $(\mathrm{N}=18)$} & \multicolumn{3}{|c|}{ Users $(n=379)$} \\
\hline & $\mathrm{M}$ & SD & Int & M & SD & Int \\
\hline Collection Management & 2.77 & 0.55 & Good & 3.54 & 0.66 & Very Good \\
\hline Services and Utilization & 3.57 & 0.54 & Very Good & 3.79 & 0.54 & Very Good \\
\hline Physical Facilities & 3.19 & 0.74 & Good & 3.36 & 0.66 & Good \\
\hline IT Facilities and Services & 2.04 & 0.85 & Poor & 2.47 & 0.87 & Poor \\
\hline Over-all Assessment & 2.89 & 0.50 & Good & 3.29 & 0.57 & Good \\
\hline
\end{tabular}

\section{Implementation of sustainable practices in greening public libraries}

Overall, administrators rated great the extent of implementation of sustainable practices in greening public libraries as indicated by Mean $=3.71, S D=0.76$, while users find it to a moderate extent with Mean=3.46, SD=0.51, interpreted as such. The disparity of rating is attributed to the assessor's role (implementers and beneficiaries), and the amount of time they spent in the library. Furthermore, among the parameters cited, both types of assessors gave the highest rating $(M=4.24$, $\mathrm{SD}=0.78) ;(\mathrm{M}=3.78, \mathrm{SD}=0.58)$ to location and the least rating $(\mathrm{M}=3.39, \mathrm{SD}=0.90)$; $(\mathrm{M}=3.29, \mathrm{SD}=0.72)$ to materials and resources.

Accessibility and proximity saved administrators and users time, effort, and money since public libraries could be easily reached either by foot, bicycle or by public transport. It was also found that public libraries were greatly implementing the use of recycled paper for borrower's slip, book pocket, and inter-office communication, as well as in the provision of labeled waste containers for proper waste segregation. However, e-mail, internet, online resources, and eco-friendly furniture and fixtures like bamboo and woods were least used. Likewise, they do not have an area for the recovery of solid wastes. The finding is in harmony with Tolan (2013) and Yuan et al. (2017) that location or site attributed to green practices. It also corroborates with findings of Nikam (2013) and Agashe (2013) that the use of the biodegradable material is one venture of making the green library. However, the moderate use of ICT-based tools like email, telephone, and internet as a part of the communication system is in discord with Husain and Nazim (2015) wherein these devices are being used as a part of the communication system by most of the libraries. 
The result denotes that the public library's effort to implement green practices to minimize the negative impact a library operation could bring on the environment was admirable. The findings showed great inclusion of sustainable principles and practices in the library's daily operation. The theory of green library management is validated by the existing greening initiatives being implemented by public libraries in the province. These initiatives spawn positive outcomes congruent with the desired goal of having a library that is user and environment-friendly.

Table 3. Extent of Implementation of Sustainable Practices in Greening Public Libraries

\begin{tabular}{lcclcccl}
\hline \multicolumn{1}{c}{ Areas } & \multicolumn{3}{c}{ Administrators (N=18) } & \multicolumn{3}{c}{ Users (n=379) } \\
& $\mathrm{M}$ & SD & \multicolumn{1}{c}{ Int } & M & SD & Int \\
\hline Location & 4.24 & 0.78 & Great & 3.78 & 0.58 & Great \\
Power and Utilities & 3.57 & 0.84 & Great & 3.41 & 0.70 & Moderate \\
Materials and Resources & 3.39 & 0.90 & Moderate & 3.29 & 0.72 & Moderate \\
Indoor Environment & 3.91 & 0.99 & Great & 3.50 & 0.62 & Great \\
Operations and Design & 3.46 & 0.95 & Moderate & 3.34 & 0.58 & Moderate \\
\hline
\end{tabular}

Note: 4.50-5.0=Very Great, 3.50-4.49=Great, 2.50-3.49=Moderate, 1.50-2.49=Less, 1.0-1.49=Least

\section{Challenges of Public Libraries}

Public library administrators identified budget constraint, low priority/minimal interest from local officials, lack of licensed librarian, lack of awareness of RA 7743, and lack of legal sanctions for noncompliance with public library law as the five topmost challenges they came across in meeting the provisions of RA 7743. The lack of/poor ICT services and facilities (e.g., internet, WiFi connection, computer units), insufficient space, and their difficulty in organizing library collection based on universal system of classification impede their goal of delivering the highest level of performance while the high cost of green building construction or renovation and subscription of e-resources, and the inadequate knowledge and exposure on green initiatives, and the lack of relevant materials like books, brochures, film, etc. to promote environmental preservation and conservation most likely hinders their persuasion of implementing sustainable practices to a very great extent.

Chandrasekar (2013); Katz (2017); and Widdersheim and Koizumi (2016) emphasized that public libraries are political entities that need support from local leaders and the general public. Salman, Mostert, and Mugwisi (2018) also stated that impediments to good library management were the lack of funding, lack of engagement of stakeholders in public library administration, and unsuitable public library legislation. Moreover, Diaz (2017) and Spodick (2016) believed that it is necessary for the administrators to position sustainable planning and design throughout various library processes, for greening does not indulge much money. It lies in the ingenuity and resourcefulness of people who implement the said practices.

Library users, on the other hand, have a different accord on how a particular library is performing as recipients of the services. The result pinpointed that aside from the poor IT facilities and services, the passive relationship between the library and surrounding community, the inadequacy of resources (books, periodicals, government publications, multimedia, and e-resources) and the limited opening hours to cater the needs of diverse users especially the students affects public libraries performance. 
Results of the studies of Iroaganachi and Nkiko (2016); Kaur and Walia (2013); Mwanzu and Wendo (2017); and Shafique and Mahmood (2013) supports the above findings. Mwanzu and Wendo pointed out that public libraries with sufficient resources and functional services would be of great value to communities.

Furthermore, users also found that the inadequate knowledge and exposure to green initiatives, the lack of relevant references specifically on greening topics, the unavailability of signage and eco-friendly reminders, and the poor implementation of environment-friendly policies are the prevailing challenges that hinder public libraries in implementing sustainable practices to the greatest extent. Suresh Kumar and Antoo (2013) and Datta (2015) emphasized that for the library to gain a "green image," they have to have suitable and relevant information on green issues and concerns. Attaran and Celik (2015); Hauke and Werner (2013), (Yi (2016), Granger (2017), and Hafit and Abdullah (2017) coherently stated that the integration of the sustainable practices in the library's operational activities which users could felt is instrumental towards the provision of clear green identity.

The result implies that while appropriate policy directives exist, the level of success in implementing such policies is influenced first and foremost by local initiatives, actions, and resources. It is inferred that broad knowledge and understanding of the local authorities, those managing the library, and the community of the vital role public libraries play in nation-building shaped its overall performance. Budget constraint, scarcity of professional librarians, and least support from local officials widened the gap between the ideal and actual condition of public libraries in the province. The research is a revelation that against this backdrop, public libraries are facing challenges to develop and remain sustainable, inclusive, interactive, and empowering learning community, particularly now in the context of intense information and technological environment and economic turmoil.

\subsection{Conclusion}

The future of public library seems to depend on the thrusts of the local government unit, knowledge and familiarity of the law, perception, and understanding of the role and function of the library in a community, availability of the competent manpower in the field of librarianship, adequacy of financial resources, the will of the librarians and officers in charge to initiate and maintain good relationship among stakeholders, and rigid monitoring as to the enforcement of the law. The absence of sanctions for non-compliance in the implementing rules and guidelines of the law and the observance of the decentralization principle among local government units defray the current state of public libraries in the province. Furthermore, modern services that respond to user needs and expectations, provision of flexible and adaptable spaces where meaningful interactions can take place, and where people can easily access curated information both in physical and digital form is the key to achieving a high level of performance rating. The implementation of sustainable strategies in the day to day operations and procedures of the library is a proactive step in promoting environmental values exemplified by various greening programs, practices, initiatives, and actions for current and future users to guarantee the protection of the world's resources for future generations. 
The challenges encountered both by the administrators and users are the aftermath of their failed expectations. It conveys a clear message that the quality, efficiency, and development of public libraries, as a social service under local government, fall short as per the implementing rules and guidelines of the established law, minimum requirement of the developed standard, and philosophy of being in the forefront in implementing greening practices. With strategic direction, utmost support, and the right investment, public libraries could be well-placed to provide knowledge and opportunities to communities.

\subsection{Recommendations}

The national and local governments may establish a cohesive vision and direction for public libraries to be relevant and high-achieving public service organizations in today's society. Ratification of the existing law to include in the provision a certain percentage of the yearly budget and sanctions for noncompliance may be considered. Likewise, support to the improvement of infrastructure and facilities, increase and hiring of qualified human resources, an increase of learning resources, and fund allocations may be given priority.

Public libraries, being a logical partner for community development initiatives, need to forge stronger partnerships with community groups, government, and business in order to provide a broad range of information services to diverse constituencies. Community connection may be strengthened by demonstrating paramount value as conduits of learning, culture, and social context. They may convey decision-makers of its potential impact and breadth through relevant and proactive services and programs in a building that is a landmark of the locality.

\section{REFERENCES}

Abban, S. (2018). Training and Development of Library Staff: A Case of Two University Libraries in Ghan. Library Philosophy and Practice (e-journal). Retrieved from https://digitalcommons. unl.edu/libphilprac

Agashe, P.A. (2013). Green libraries initiatives at international level and prospects in India. e-Library Science Research Journal, 1(7).

Agudelo, R. (2014). A journey of purpose reflections on Philippine libraries and librarianship. OLA Quarterly, 71(1), 20-28. Retrieved from http://dx.doi.otg/10.7710/1093-7374.1573

Alaya-ay, G. (2013). Implementation status of public libraries' enabling laws: the Cagayan-Iligan Corridor and Misamis Oriental experiences. International Journal of Education and Research, 3 (9), 1-30.

Attaran, S. and Celik, B.G. (2015), "Students' environmental responsibility and their willingness to pay for green buildings," International Journal of Sustainability in Higher Education, Vol. 16 No. 3, pp. 327-340. [Google Scholar] [Link], [ISI] [Infotrieve]

Austria, M.A.C. \&Lozarie, D.B.A. (2014). Long overdue: an investigative study on the state of the Philippine public library system, Unpublished Thesis, University of the Philippines College of Mass Communication. 
Baxter, P. (2015). The United Kingdom and Ireland. Fontes Artis Musicae, 62(4), 385-388. Retrieved from https://search.proquest.com1833905119?accountid $=34542$

Bell, B., \& Cottrell, T. L. (2015). Library interior design, costs, and implications for the future. The Bottom Line, 28(4), 122-125. Retrieved from https://search.proquest.com/ docview $/ 1735314225$ ?accountid $=34542$

Biranvand, A., Soheili, F., \&Khasseh, A. (2015). Creativity of librarians in public libraries: a Case study of public libraries of Fars Province (Iran). Library Philosophy and Practice, 0_1,1-17. Retrieved from https://search.proquest.com/docview/ 1785387687 ?accountid $=34542$

Carungui, D. (2015). Governance innovations in Philippine Public Libraries. Lien Conference, Singapore.

Chandrasekar, K. (2013). Public libraries in Jaffna district, Sri Lanka - challenges. Library Philosophy and Practice, 1-19. Retrieved from https://search.proquest.com/ docview/1441487750?accountid=34542

Datta, S. (2015). Green is the new black: bringing the libraries into the green scene. International Journal of Digital Library Services, 5(3), 59-68. Retrieved from http://www.ijodls.in/ uploads/3/6/0/3/3603729/7535.pdf on November 4, 2017

De Leon, H. \& De Leon, H., Jr. (2017). Philippine constitutional law: principles and cases. Manila: Rex Book Store

Deloso, J. (2010). The performance of public libraries in Negros Occidental. Unpublished Dissertation. West Negros University, Bacolod City.

Dias, S. M. (2017). Environmental sustainability for public libraries in Portugal: A first approach. Electronic Green Journal, (40), 1-15. Retrieved from https://search.proquest.com/ docview/1877714535?accountid=34542

Ephraim, P. (2003), “The greening of libraries", Library Management, Vol. 24 No. 3, pp. 160-163. https://doi.org/10.1108/01435120310464862

Etzioni, A. (1964). Modern organizations. Englewood Cliffs, NJ: Prentice-Hall, Inc.

Granger, L. (2017). Leading the Green Revolution. American Libraries Magazine, 51-53.

Hafit, A. and Abdullah, C. (2017). Implementation of green technology in library: a proposed framework. International Journal of Academic research in Business and Social Sciences, 7(12), 507-514. Retrieved from http://dx.doi.org/10.6007/ UARBSS /v7-112/3631

Handa, T. (2018). Role of public library in the society and a future vision of ICT enabled rendering of its services with special context to India. Retrieved from https://www.researchgate. net/publication/265202196. [Accessed March 15, 2018]

Hauke, P. \& Werner, K. (2013). Going green as a marketing tool for libraries: environmentally sustainable management practices. In IFLA WLIC. Retrieved 12/07, 2016 library.ifla. orq/147/1/086-hauke-en.pdf

Hauke, P., Gunwald, M., \& Wilde, A. (2014). Green libraries coming up! National and international initiatives fostering environmental sustainable libraries and library services. Retrieved from http://www.ibi.huberlin.de/de/studium/studprojekte/buchidee/bi12/bob14 
Hopwood, S. (2014). Successful social networking in public libraries. Reference \& User Services Quarterly, 53(4), 370. Retrieved from https://search.proquest.com/ 1542401559

Husain, S., \& Nazim, M. (2015). Use of different ICT in Indian academic libraries. Library Review, 64(1), 135-153. DOI.org/10.1108/LR-04-2014-0070

IFLA (2010). IFLA public library service guidelines. Berlin ; New York: De Gruyter/Saur, 2nd, completely rev. ed. / edited by Christie Koontz and Barbara Gubbin

Iraoganachi M. and Nkiko, C. (2015). Performance assessment model for academic libraries: the covenant university library sample. Annual of Library and Information Studies, 63, 7-15.

Iwhiwhu, B. and Okorodudu, P. (2013). Public library information resources, facilities, and services: user satisfaction with Edo State Central Library, Benin-City, Nigeria. Library Philosophy and Practice (e-journal). Retrieved from https://digitalcommons.unl.edu/cgi/viewcontent. cgi?article $=1821 \&$ context=libphilprac

Kaur, P., \&Walia, P. K. (2015). Collection development and management within public libraries in Delhi. Library Management, 36(1), 99-114. Retrieved from https://search.proquest.com/ docview/1643109237?accountid=34542

Katz, A. (2017). Philippine libraries march into the $21^{\text {st }}$ century. Beyond Access (online). Retrieved from https://beyondaccess.net/2017/04/03/philippines-libraries/ on June 2, 2018

Laspinas, M. (2014). SPPL-based assessment of public libraries. European Scientific Journal, 10 (1), 78-9. Retried from https://eujournal.org/index.php/esj

Lee, K. S. (2015). A Framework of Channel Membership Involvement: Alienative, Calculative, and Moral Attitudinal Orientation. In: Bahn K. (eds) Proceedings of the 1988 Academy of Marketing Science (AMS) Annual Conference

Michnik, K. (2015). Public libraries digital services and sustainability issues. The Bottom Line: Managing library finances, 28 (1/2), 34-43, http://doi.org.10.1108/BL-12-2014-0034

Michnik, K. (2015). Public library managers' description of political attention. Library Management, 36 (8/9), 673-684, http://doi.org.10.1108/LM-04-2015-0013

Mwanzu, A., \&Wendo, D. R. (2017). Re-branding libraries to embrace open space and aesthetic reflections: A case of USIU-Africa as a benchmark of Kenyan libraries. Library $\mathrm{Hi}$ Tech News, 34(1), 6-10. Retrieved from https://search.proquest.com/ docview/1874382635?accountid $=34542$

Myers, M. \&Heddon, D. (2017). On Libraries: an introduction, performance research, 22:1, 1-8, DOI:1080/13528165.2017.1285554

Nikam, S. (2017). Green library: an emerging concept. "Knowledge Librarian": An International Peer Reviewed Billingual E-Journal of Library and Information Science, 4 (1), 190-198. Retrieved from www.klibjlis.com/sp2018apr16

Official Gazette (1994). RA 7743- An act providing for the establishment of congressional, city, and municipal libraries and barangay reading centers throughout the Philippines, appropriating the necessary funds therefor and for other purposes. Vo. 90, No. 30, August 15, 1994. 
Orlopia, A and Rabaca, S. (2015). Assessment of the Midsayap municipal public library fiscal year 2014- 2015. Undergraduate Thesis. College of Arts and Sciences, Southern Christian College, Midsayap, Cotabato.

Otolo, P. U. (2016). Globalization, modernization and functionality of the public library system in Nigeria. Library Management, 37(8), 426-440. Retrieved from https://search.proquest. com/1846005585?accountid $=34542$

Pieprz, D. \&Sheth, R (2017). Singapore and Mexico are inventing the $21^{\text {st }}$-century campus. Planning for Higher Educatio, (45(2), 90-106. Retrieved from https://search.proquest. com $/ 1846005585$ ?accountid $=34542$

Quick, et al (2013). "Cross-European public library study, country reports, available at http:// tascha, uw.edu/tasha.uw.edu/publications-resources (accessed July 10, 2017)

Rudzioniene, J., \& Dvorak, J. (2014). Public administration approach. Library Management, 35(6), 495-507. Retrieved from https://search.proquest.com/ docview/1633971447?accountid=34542

Salman, A., Mostert, J., and Mugwisi, T. (2018). The governance and management of public library services in Nigeria. Library Management, 39 (6-7), 389-401, https://doi.org/10.1108/LM08-2017-0075

Santos, A. (2015). 2014 National Library of the Philippines annual report. Retrieved from http:// web.nlp.gov.ph/nlp/affiliatedlibraries/provinces (accessed June 16, 2017)

Shafique, F. and Mahmood, K. (2013). Administration of Education Enterprise and Gaps in the Provision of Needed Information: The Case of Pakistan. The Journal of Academic Librarianship, 39, 535-545.

Spodick, E. (2016) Sustainability - it's everyone's job. Library Management, 37(6/7), 286-297. Retrieved from https://doi.org/10.1108/LM-04-2016-0024

Suresh Kumar, P.K., \&Antoo K.D. (2013). Greening the library for sustainable development. Kerala University Library, Thiruvananthapuram, Prajyoti Niketan College Thrissur, Kerala.

Tabatabai, S., Karbasian, M., \&Mirbagheri, S. M. (2014). A conceptual model for performance management in organizations. Kuwait Chapter of the Arabian Journal of Business and Management Review, 3(10), 28-41.

Tolan, P. (2013). Going-going-green: strategies for fostering sustainable new federal buildings. Public Contract Law Journal, 41(2), 233-295. Retrieved from https://search. proquest.com/docview/1017544570?accountid=34542

Traska, M. R. (2015). Building a better board of trustees. American Libraries, 46(11), 32-37. Retrieved from https://search.proquest.com/docview/2122402062? accountid=34542

Vallet, N. (2013). Becoming partners in urban development: A case-study research on the strategic roles of Flemish and Dutch public libraries in the future development of cities. Library Management; Bradford Vol. 34, 8/9: 650-663 Phttps://search.proquest.com/ docview/1442847207/A1C88E1706D24E89PQ/3?accountid=34542. 
Wani, Z. (2016). Development of public libraries in India. Library Philosophy and Practice. Retrieved from http://unllib.unl.edu/LPP/Ipp.htm [Accessed April 4, 2018].

Watson, A. (2013). Green technologies and practices: A visual essay. Monthly Labor Review, 136 (1), 36-48. Retrieved from https://search.proquest.com/docview/ 1286670072 ?accountid $=34542$

Widdersheim, M. M., \& Koizumi, M. (2016). Conceptual modelling of the public sphere in public libraries. Journal of Documentation, 72(3), 591-610. Retrieved from https:// search.proquest.com/docview/1779872898?accountid=34542 Yi, Z. (2016). Knowledge management for library building design. Library Management, 37(1), 2-12. Retrieved from https://search.proquest.com/docview

Yi, Z. (2016). Knowledge management for library building design. Library Management, 37(1), 2-12. Retrieved from https://search.proquest.com/docview

Yuan, C., Sun, Y., Lv, J., \& Lusk, A. C. (2017). Cycle tracks and parking environments in china: Learning from college students at Peking University. International Journal of Environmental Research and Public Health, 14(8), 930. doi:http://dx.doi.org/10.3390/ijerph14080930 